\title{
軸方向圧縮力と曲げモーメントを受ける角形鋼管柱の構造性能評価
}

\section{STRUCTURAL PERFORMANCE EVALUATION OF SQUARE STEEL TUBULAR COLUMN UNDER COMPRESSIVE AXIAL FORCE WITH BENDING MOMENT}

\author{
佐藤篤司 ${ }^{* 1}$, 位田健 太2 $^{* 2}$, 三井和 也*3 \\ Atsushi SATO, Kenta INDEN and Kazuya MITSUI
}

\begin{abstract}
Recommendation for Limit State Design of Steel Structures and Recommendation for Plastic Design of Steel Structures specifies the requirements for the column to guarantee sufficient strength and ductility. The test results, where the square steel tubular columns are under compressive axial force with different moment distribution, were reported in the previous papers. In this paper, structural performance evaluation of square steel tubular column is conducted based on the existing test results. Collapse mode, maximum bending moment, plastic deformation capacity, and moment amplification factor are evaluated; comparison study between the current design recommendations is also shown.
\end{abstract}

Keywords : Square steel tubural column, End bending moment ratio, Maximum bending moment,

Moment amplification factor, Plastic deformation capacity

角形鋼管柱，材端曲げモーメント比，最大曲げモーメント，モーメント拡大係数，塑性変形能力

\section{1. はじめに}

箱形断面部材や角形鋼管部材といった矩形中空断面部材は，直交 する 2 方向に対し耐力・剛性が等しいという断面特性上の利点を有 していることから，建築構造物の柱材として広く使用されている. 建築物として一般的なラーメン架構に水平力が作用すると，柱には 軸方向力とともに水平力に抵抗するせん断力が生じ, 複曲率曲げモー メントが作用する．柱の応力状態（軸方向力と曲げモーメントの組 合せ応力）の変化は柱の耐力や弾塑性挙動に影響を及ぼすことから, 我が国ではこれらの影響を考慮した軸方向力と曲げモーメントの設 計耐力式が各指針・規準に示されている ${ }^{1) \sim 4)}$.

鋼構造限界状態設計指針・同解説 ${ }^{1)}$ ( 以後, LSD 指針と称す) や鋼 構造塑性設計指針 ${ }^{2)}$ (以後, 塑性指針と称す）では，軸方向力と曲げ モーメントを受ける柱に対して耐力相関式や細長比および軸力比に よる制限式を示している，軸力比と細長比の制限について，LSD 指 針および塑性指針では，塑性ヒンジを形成する柱に対して以下の条 件を満たすこととしている。

$n_{y} \leqq 0.75$

$n_{y} \cdot \lambda_{c 0}^{2} \leqq 0.10(1+\kappa)$ $(-0.5<\kappa \leqq 1.0)$

$n_{y}$ は柱の降伏軸力 $N_{y}\left(=A \cdot \sigma_{y}\right)$ に対する作用軸方向圧縮力 $N$ の比率 $(=$ $\left.N / N_{y}\right), \quad \lambda_{c 0}$ は材長 $L$ を座屈長さとする柱の曲げ面内の曲げ座屈細長比
( 以後，曲げ面内細長比と称す) である， $\lambda_{c 0}$ の算定式を (3) 式に示す。

$$
\lambda_{c 0}=\sqrt{N_{y} / N_{0}}
$$

$$
N_{0} \text { は柱の曲げ面内のオイラー座屈耐力 }\left(=\pi^{2} E I / L^{2}\right) \text { である。 } \kappa \text { は柱の }
$$
材端曲げモーメント比 $\left(=M_{2} / M_{1},\left|M_{1}\right| \geqq\left|M_{2}\right|\right)$ であり, 複曲率曲げの ときを正とする，A は断面積， $\sigma_{y}$ は降伏応力度， $E$ はヤング係数， $I$ は曲げ面内での断面二次モーメント， $L$ は材長である。制限式 (1) は 軸方向圧縮力が極めて大きくなったとき，柱のたわみに伴う付加曲 げモーメントによる不安定現象を防ぐ制限である。制限式 (2) は，材 端に塑性ヒンジを形成する柱に対し，軸方向力を保持した状態で塑 性変形能力を確保するための制限である.

上述の制限式は主として $\mathrm{H}$ 形鋼柱の実験結果 ${ }^{5)}$ に基づいて構築さ れているという背景から，筆者はこれまでに角形鋼管柱を対象とし， 軸方向圧縮力と一端単調曲げ $(\kappa=0.0)$ / 単調複曲率曲げ $(\kappa=0.5)$ / 単調 逆対称曲げ $(\kappa=1.0)$ を受ける場合の部材実験を行い, 最大曲げモー メントや塑性変形能力，変形性状について指針式との関係を考察し $た^{6,7), 81}$. しかし，これらの報告はいずれも単一の材端曲げモーメン ト比によるものであることから，一連の実験結果をまとめ各構造性 能に関して材端曲げモーメント比の影響を考慮した考察を行う必要 がある。

軸方向圧縮力と曲げモーメントを受ける角形鋼管柱の構造性能に
*1 名古屋工業大学大学院工学研究科 准教授・博士 (工学) / 情報科学フロンティア研究院

*2 元 名古屋工業大学大学院 大学院生・修士 (工学 (現 トヨタホーム(㭌)

*3 元 名古屋工業大学大学院 博士 (工学)

(現 新日鐵住金(侏鋼構造研究部)
Assoc. Prof., Graduate School of Engineering, Nagoya Institute of Technology, Dr.Eng./ Frontier Research Institute for Information Science (FRIIS)

Former Grad. Student, Nagoya Institute of Technology, M.Eng.

(Present Toyota Housing Co.)

Former Nagoya Institute of Technology, Dr.Eng.

(Present Steel Structures Research Lab., Nippon Steel \& Sumitomo Metal Co.) 
ついて, 既往研究では最大曲げモーメントや塑性変形能力, モーメ ント拡大係数に着目した考察が行われている ${ }^{9111)}$. 佐藤 ${ }^{9)}$ は幅厚比, 辺長比, 曲げモーメント勾配, 加力角度等に応じた新規幅厚比尺度 $S_{H}$ を用い, 曲げせん断力と軸圧縮力を受け局部座屈を生じる正方形 中空断面柱部材の最大曲げモーメントや塑性変形能力を評価してい る. 津田・城戸ら ${ }^{10,11)}$ は軸力と曲げを受ける柱に対して, 材端曲げモー メント比や軸力比, 細長比を変数としてモーメント拡大係数を解析 的検討により示している。こうした研究により軸方向圧縮力と曲げ モーメントを受ける角形鋼管柱の構造性能は明らかになりつつある が，実部材実験結果に基づいて評価を行った研究は少ない。

そこで本研究では，軸方向圧縮力と材端曲げモーメント比 $(\kappa=0.0$, $0.5,1.0)$ の異なる 3 種類の曲げモーメントを受ける角形鋼管柱の実験 データベースを作成し，材端曲げモーメント比の影響を考慮した崩 壊形式/最大曲げモーメント/塑性変形能力について, LSD 指針・塑 性指針との比較検討を行い, 現行指針の妥当性や改善点を示すこと を目的とする。

\section{2. 軸方向圧縮カと曲げモーメントを受ける角形鋼管柱の実験結果}

\section{1. 試験体条件}

軸方向圧縮力と単調曲げモーメントを受ける角形鋼管柱の実験条 件および実験結果を, 既報研究 ${ }^{6-8)}$ から収集する。ここで材端曲げ モーメント比 $\kappa=1.0$ の実験については, 既報 ${ }^{8)}$ と同様の載荷手法に より追加実験を行ったことから実験結果に加えることとする．鋼材 は冷間成形角形鋼管の STKR400 であり，断面形状は $\square-150 \times 150 \times 9$, $\square-125 \times 125 \times 6$ である.この断面形状における公称幅厚比はそれぞれ 16.7, 20.8であり，これは LSD 指針における P-I-1 区分の条件を満た す值である．試験体パラメー夕は軸力比および曲げ面内細長比であ る. Table 1 に JIS 5 号試験片による鋼材の機械的性質を, Table 2 に 実験で使用した角形鋼管の断面諸性能を示す，表中の「Add」は追加 実験に用いた部材の特性值を示している。素材試験片は角形鋼管の シーム溶接部を除く 3 面の平板部から各 1 本ずつ採取し, その平均 值を Table 1 に示している. 降伏応力度 $\sigma_{v}$ はいずれも $0.2 \%$ オフセッ 卜耐力を用いている.

本研究で対象とする試験体の一覧を Table 3 に示す. Table 3 中の試 験体 No. $36 \sim 38$ の 3 体が追加実験の試験体である. 表中の曲げ面内 細長比 $\lambda_{c 0}$ は素材引張試験より得た降伏応力度 $\sigma_{v}$ に基づいて算定した。 Table 3 中の $M_{p c}$ は軸方向力を考慮した全塑性モーメント ${ }^{1), 2)}$ であり, 以下の式で算定される.

$$
\begin{aligned}
& n_{y} \leqq \frac{A_{1}}{A} \text { のとき } \quad M_{p c}=\left\{1-\frac{A^{2}}{\left(4 \cdot A_{2}+A_{1}\right) \cdot A_{1}} \cdot n_{y}^{2}\right\} M_{p} \\
& n_{y}>\frac{A_{1}}{A} \text { のとき } \quad M_{p c}=\left\{\frac{2 \cdot A}{4 \cdot A_{2}+A_{1}} \cdot\left(1-n_{y}\right)\right\} M_{p}
\end{aligned}
$$

(4) 式は塑性指針が定める算定式に則っており， $A_{1}$ は板要素 1 の断 面積 $(=2 \cdot t \cdot(B-2 t)), A_{2}$ は板要素 2 の断面積 $(=B \cdot t)$ である.

$\theta_{p c}$ は軸方向力を考慮した全塑性モーメント $M_{p c}$ に対応する弾性回転 角であり，座屈たわみ角法に基づいて算定される ${ }^{12}$. $\theta_{p c}$ の算定式は 以下の通りである。

$$
\begin{aligned}
& \theta_{p c}=M_{p c} \cdot \frac{L}{E I} \cdot \frac{1-c \kappa}{s(1+c)(1-c)} \\
& \text { ただし, } \\
& \qquad c=\frac{\alpha-\sin \alpha}{\sin \alpha-\alpha \cos \alpha}
\end{aligned}
$$

\begin{tabular}{|c|c|c|c|c|c|c|}
\hline Ref. & $t_{b}$ & $E$ & $\sigma_{y}$ & $\sigma_{u}$ & $E_{\text {long }}$ & $Y . R$. \\
\hline \multirow{2}{*}{ 6) } & 6.0 & 201800 & 405.2 & 454.0 & 28.8 & 89.3 \\
\hline & 9.0 & 211200 & 386.7 & 459.1 & 35.2 & 84.2 \\
\hline 7) & \multirow{3}{*}{6.0} & 213900 & 367.2 & 438.7 & 36.7 & 83.7 \\
\hline 8) & & 211700 & 411.6 & 443.1 & 34.5 & 92.9 \\
\hline Add & & 211200 & 394.9 & 448.3 & 31.0 & 88.1 \\
\hline
\end{tabular}

Table 1 Material properties from coupon test

$t_{b}$ : Nominal thickness $[\mathrm{mm}], E$ : Young's modulus $\left[\mathrm{N} / \mathrm{mm}^{2}\right], \sigma_{v}$ : Yield stress [N/ $\left.\mathrm{mm}^{2}\right], \sigma_{u}$ : Ultimate stress [N/mm $\left.{ }^{2}\right], E_{\text {long }}$ : Elongation [\%], Y.R.: Yield ratio[\%]

Table 2 Geometrical dimensions of cross section

\begin{tabular}{c|c|c|c|c|c|c|c|c|c}
\hline Ref. & Cross section & $B$ & $t$ & $B / t$ & $R_{\text {out }} / t$ & $A$ & $I$ & $Z_{p}$ & $M_{p}$ \\
\hline
\end{tabular} \begin{tabular}{c|c|c|c|c|c|c|c|c|c}
\hline & $\square-125 \times 125 \times 6$ & 125.0 & 5.83 & 21.5 & 1.72 & 2707 & 632.4 & 119.9 & 48.58 \\
\cline { 2 - 7 }
\end{tabular} 6) \begin{tabular}{l|l|l|l|l|l|l|l|l|l}
\hline & $-125 \times 125 \times 6$ & 125.0 & 5.83 & 21.5 & 1.72 & 2707 & 632.4 & 119.9 & 88.58 \\
\cline { 2 - 10 } & $\square-150 \times 150 \times 9$ & 150.2 & 8.67 & 17.3 & 1.81 & 4713 & 1540 & 246.5 & 95.32 \\
\hline
\end{tabular} \begin{tabular}{l|l|l|l|l|l|l|l|l|l}
\hline 7$)$ & & 125.1 & 5.58 & 22.4 & 2.50 & 2561 & 595.3 & 113.0 & 41.49 \\
\hline
\end{tabular} \begin{tabular}{c|c|c|c|c|c|c|c|c|c}
\hline 8$)$ & $\square-125 \times 125 \times 6$ & 125.0 & 5.76 & 21.7 & 1.79 & 2674 & 624.8 & 118.4 & 48.75 \\
\hline
\end{tabular} Add \begin{tabular}{|l|l|l|l|l|l|l|l|}
\hline 125.1 & 5.63 & 22.2 & 2.14 & 2602 & 607.9 & 115.2 & 45.47 \\
\hline
\end{tabular}

$B:$ Width [mm], $t$ :Thickness [mm], $R_{\text {out }}:$ Outer radius [mm], $A$ : Area [ $\mathrm{mm}^{2}$ ], $I$ : Moment of inertia $\left[\times 10^{4} \mathrm{~mm}^{4}\right], Z_{p}$ : Plastic section modulus $\left[\times 10^{3} \mathrm{~mm}^{3}\right]$, $M_{p}$ : Full plastic bending moment $[\mathrm{kN} \cdot \mathrm{m}]$

Table 3 List of specimens

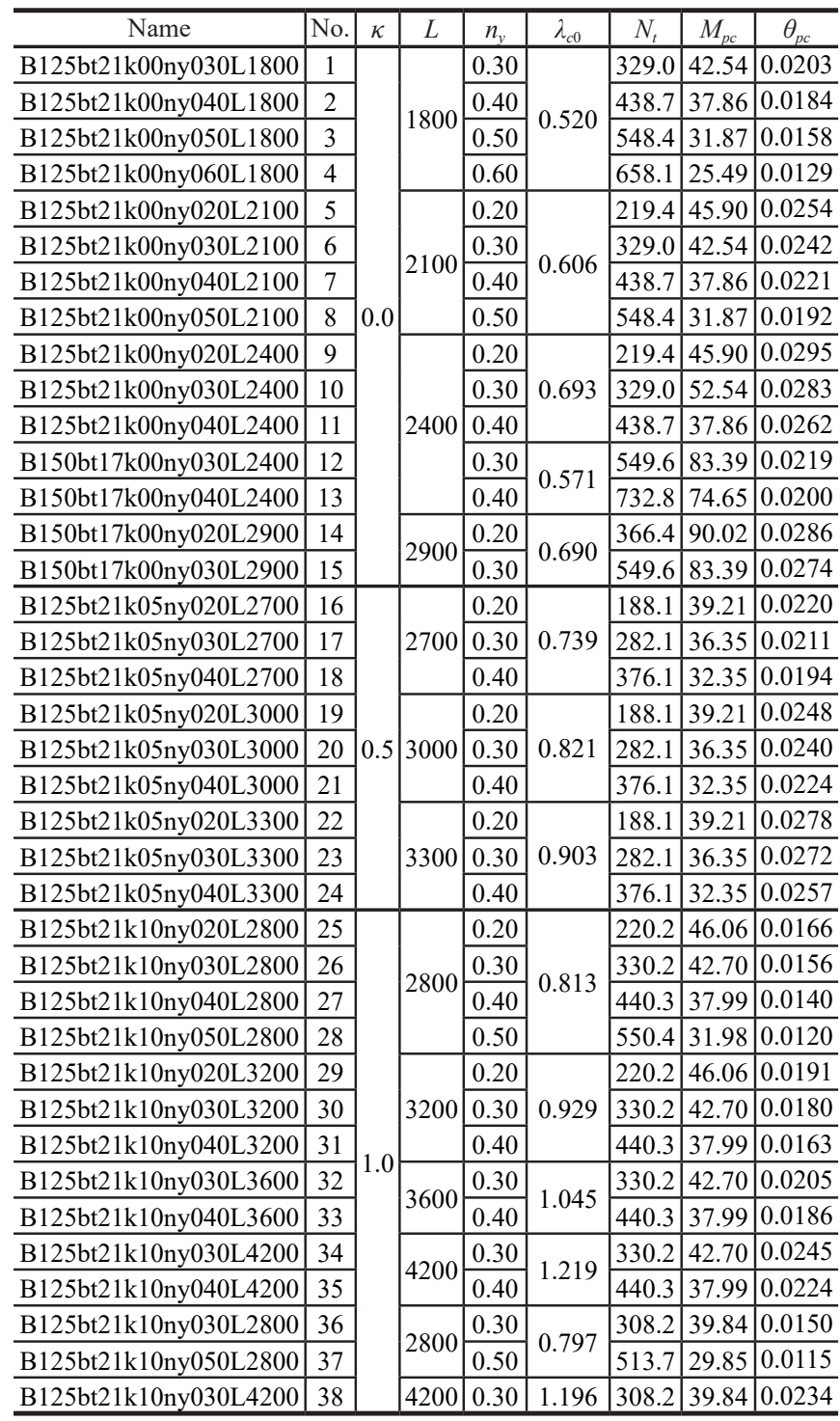

$\kappa$ : End bending moment ratio, $L$ : Length $[\mathrm{mm}], n_{y}$ : Compressive axial force ratio, $\lambda_{c 0}$ : Flexural slenderness ratio, $N_{t}$ : Target compressive axial force $[\mathrm{kN}]$, $M_{p c}$ : Full plastic bending moment considering the effect of compresive axial force $[\mathrm{kN} \cdot \mathrm{m}], \theta_{p c}:$ Elastic rotation corresponding to $M_{p c}[\mathrm{rad}]$ 


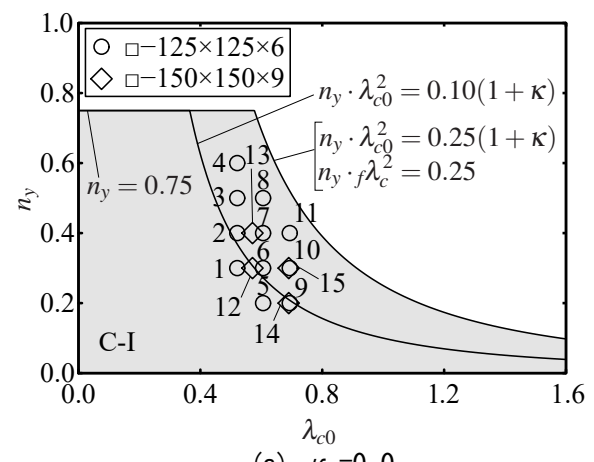

(a) $\kappa=0.0$

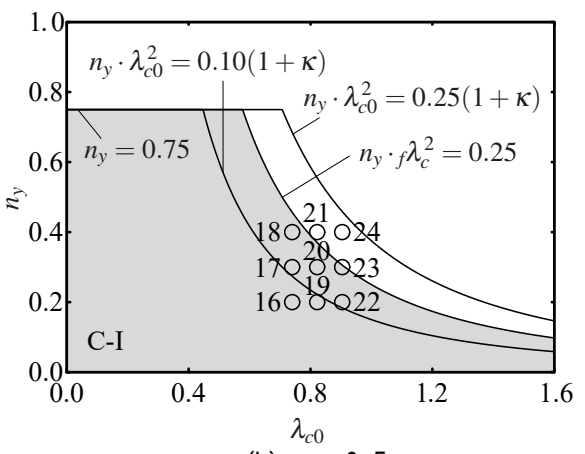

(b) $\kappa=0.5$

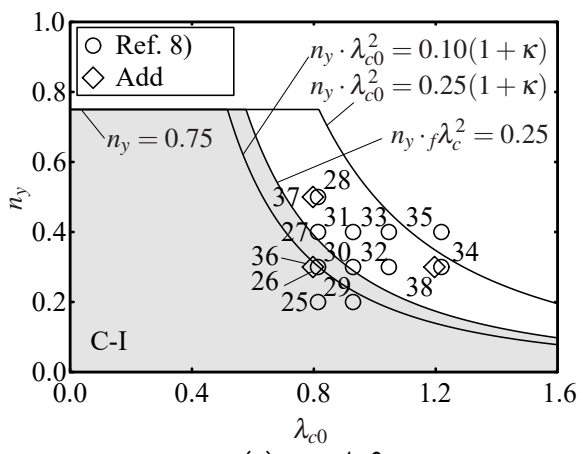

(c) $\kappa=1.0$

Fig. 1 Comparison between specimens and LSD Iimitaions

$$
\begin{aligned}
s & =\frac{\sin \alpha-\alpha \cos \alpha}{2(1-\cos \alpha)-\alpha \sin \alpha} \cdot \alpha \\
\alpha & =\pi \sqrt{\frac{N_{y} \cdot n_{y}}{N_{0}}}
\end{aligned}
$$

本実験において導入軸方向圧縮力 $N_{t}$ は, Table 1 に示す素材引張試 験より得た降伏応力度 $\sigma_{y}$ に Table 2 に示す断面の実測寸法に基づく断 面積 $A$ を乗じることで求めた降伏軸力 $N_{y}\left(=A \cdot \sigma_{y}\right)$ に基づいて算出し た。 その值を Table 3 に示している. 試験体名は記号「B」に続く数 字が断面せいを,「bt」に続く数字が公称幅厚比を，「ny」に続く数字 が軸力比を, $「 \mathrm{~L} 」 に$ 続く数字が材長をそれぞれ意味しており, 既報 ${ }^{6-8)}$ に加え新たに材端曲げモーメント比を示す「k」を示している.

Table 3 に示す全試験体について, LSD 指針および塑性指針の定め る軸力比・細長比による制限式との対応関係を材端曲げモーメント 比別で Fig. 1 に示す. 図中の番号は Table 3 に示す試験体番号である. また Fig. 1 には, 軸方向圧縮力と曲げモーメントを受ける柱の材端に 塑性ヒンジを形成する柱が塑性変形能力を確保するための制限式 (2) と, 材端に初期降伏が生じる条件式 (6) ${ }^{1,2)}$ を同時に示している.

$$
n_{y} \cdot \lambda_{c 0}^{2} \leqq 0.25(1+\kappa)
$$

LSD 指針・塑性指針に示される制限式 (2) は条件式 (6) 中の数値 0.25 を 0.10 と小さく設定することで定められたものである ${ }^{5)}$. さら に LSD 指針・塑性指針では, 終局状態において塑性ヒンジが形成さ れる骨組，特に高軸方向圧縮力が作用する骨組および高層骨組にお ける「フレームスタビリティ」を確保するために，(1) 式に加え (7) 式を設けている，LSD 指針では，これらの制限を満たす柱を C-1 区 分としている. Fig. 1 に示すように，C-1 区分となる軸力比と細長比 の組合せは灰色で塗られた領域である。

$$
n_{y} \cdot f \lambda_{c}^{2} \leqq 0.25
$$

ここで, (7) 式中の ${ }_{f} \lambda_{c}$ は構面内の柱の曲げ座屈細長比であり, 本実 験においては先述の $\lambda_{c 0}$ に等しい.

\section{2. 実験結果}

Table 4 に実験結果一覧を示す．Table 4 中における有効数字は既報 6)-8) と同一としている。 $M_{i}$ は試験体に設けた各変位計測位置における 付加曲げを考慮した曲げモーメントの最大值である. 付加曲げモーメ ントは面内変位量 $\delta_{i}$ ( $i$ は変位計測位置) に作用軸方向圧縮力 $N$ を乗 じて求められる。ここで追加実験試験体 (No.36 No.38) は, 面内変位 量 $\delta_{i}$ の測定を簡易的に行ったことから参考值として取り扱う。

$R$ は塑性変形能力を意味しており，次式で算出される.

$$
R=\theta_{u} / \theta_{p c}-1
$$

\begin{tabular}{|c|c|c|c|c|c|c|c|}
\hline & No. & $M_{\max }$ & $M_{i} / M_{\max }$ & $\theta_{\max }$ & $\theta_{u}$ & $R$ & $\mathrm{M}$ \\
\hline B125bt21k00ny030L1800 & 1 & 52.73 & & & & 4.26 & $\mathrm{~L}$ \\
\hline B125bt21k00ny040L1800 & 2 & 45.41 & 0.997 & 0.0750 & 0.132 & 6.17 & $P \delta+\mathrm{L}$ \\
\hline $125 \mathrm{bt} 21 \mathrm{k} 00 \mathrm{ny} 050 \mathrm{~L} 1800$ & 3 & 36.88 & 1.007 & 0.0522 & 0.092 & 4.82 & $P \delta$ \\
\hline & 4 & 28.29 & 1.025 & 0.0402 & 0.063 & 3.86 & $P \delta$ \\
\hline & 5 & 56.58 & 940 & & 136 & 4.35 & $\mathrm{~L}$ \\
\hline & 6 & 50.87 & 0.991 & 0.0935 & 0.151 & 5.27 & $P \delta+\mathrm{L}$ \\
\hline & 7 & 42.92 & 1.016 & 0.0724 & 0.119 & 4.37 & $P \delta$ \\
\hline & 8 & 33.73 & 1.047 & 0.0511 & 0.068 & 2.57 & $P \delta$ \\
\hline & 9 & 54.20 & 0.977 & 0.1198 & 0.169 & 4.73 & $\mathrm{~L}$ \\
\hline & 10 & 46.96 & 0.991 & 0.08 & 0.149 & 4.25 & $P \delta$ \\
\hline & 11 & 39.87 & 1.016 & 0.0651 & \begin{tabular}{|l|l|}
0.087 \\
\end{tabular} & 2.31 & $P \delta$ \\
\hline & 12 & 100.3 & 0.997 & 0.1032 & 0.174 & 6.95 & $P \delta$ \\
\hline & 13 & 80.88 & 1.027 & 0.0701 & 0.108 & 4.42 & $P \delta$ \\
\hline & 14 & 102.3 & 1.043 & 0.1210 & 0.225 & 6.87 & $P \delta+\mathrm{L}$ \\
\hline & 15 & 87.42 & 1.127 & 0.0 & 0.122 & 3.45 & $P \delta$ \\
\hline & 16 & \begin{tabular}{|l|}
47.41 \\
\end{tabular} & 0.900 & & 79 & 3.90 & \\
\hline & 17 & 42.73 & 0.967 & 0.09 & 0.1155 & 4.48 & $\mathrm{~L}$ \\
\hline & 18 & 35.10 & 0.980 & 0.0626 & 0.1033 & 4.32 & $P \delta$ \\
\hline & 19 & 47.22 & 0.932 & 0.1018 & 0.1206 & 3.86 & $\mathrm{~L}$ \\
\hline & 20 & 41.29 & 0.992 & 0.0872 & 0.1497 & 5.23 & $P \delta$ \\
\hline & 21 & 34.80 & 1.017 & 0.0609 & 0.0873 & 2.90 & $P \delta$ \\
\hline & 22 & 46.69 & 0.968 & 0.1160 & 0.1381 & 3.97 & $\mathrm{~L}$ \\
\hline & 23 & 38.51 & 1.003 & 0.07 & 0.1188 & 3.37 & $P \delta$ \\
\hline & 24 & 30.81 & 1.067 & 0.0626 & & - & $P \delta$ \\
\hline & 25 & 54.15 & 0.831 & 0.0583 & 0.0769 & 3.63 & $\mathrm{~L}$ \\
\hline & 26 & 49.59 & 0.860 & 0.0652 & 0.0813 & 4.22 & $\mathrm{~L}$ \\
\hline & 27 & 42.50 & 0.931 & 0.0738 & 0.0965 & 5.88 & $P \delta+\mathrm{L}$ \\
\hline & 28 & 34.65 & 0.958 & 0.0536 & 0.0830 & 5.95 & $P \delta$ \\
\hline & 29 & 53.54 & 0.872 & 0.0669 & 0.0865 & 3.52 & $\mathrm{~L}$ \\
\hline & 30 & 47.71 & 0.904 & \begin{tabular}{|l|}
0.0707 \\
\end{tabular} & \begin{tabular}{|l|}
0.0847 \\
\end{tabular} & 3.71 & $\mathrm{~L}$ \\
\hline & 31 & 41.08 & 0.948 & 0.0651 & 0.1126 & 5.93 & $P \delta$ \\
\hline & 32 & 52.60 & 0.946 & 0.1013 & 0.1234 & 5.02 & $P \delta+\mathrm{L}$ \\
\hline & 33 & 42.58 & 0.975 & 0.0683 & 0.1155 & 5.21 & $P \delta$ \\
\hline & 34 & 45.17 & 0.988 & 0.0750 & 0.1204 & 3.92 & $P \delta$ \\
\hline & 35 & 34.92 & 1.034 & 0.0586 & & & $P \delta$ \\
\hline & 36 & 51.22 & $0.845^{*}$ & 0.0622 & 0.0790 & 4.28 & $\mathrm{~L}$ \\
\hline & 37 & \begin{tabular}{|l|}
43.37 \\
\end{tabular} & $0.883^{*}$ & 0.0703 & 0.1177 & 9.27 & $P \delta$ \\
\hline B125bt21k10ny030L4200 & 38 & |49.61 & $0.965^{*}$ & 0.0877 & 0.1634 & 5.98 & $P \delta$ \\
\hline
\end{tabular}

式中の $\theta_{u}$ は材端での曲げモーメントが全塑性モーメント $M_{p c}$ を超え
Table 4 Test results

$M_{\text {max }}$ : Maximum bending moment[kN.m], $M_{i}$ : Maximum conbined bending moment at measurement point $[\mathrm{kN} \cdot \mathrm{m}], \theta_{\max }$ : Rotation at the maximum bending moment $[\mathrm{rad}], \theta_{u}$ : Ultimate rotation $[\mathrm{rad}], R$ : Plastic deformation capacity, C.M.: Collapse mode, $※:$ Reference value

最大曲げモーメント $M_{\text {max }}$ に至り, 変形を伴い耐力劣化をはじめ, (9) 式に到達した時の材端回転角である.

$M_{u}=\min \left(0.90 M_{\max }, M_{p c}\right)$

また, C.M. は実験で確認された崩壊形式を示しており, L は曲げモー 


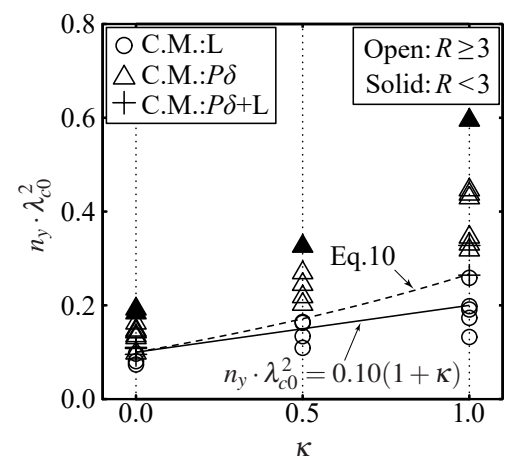

Fig. 2 Comparison between collapse mode and Eq. 2

メント載荷点付近に発生した局部座屈により載荷点の最大曲げモー メントおよび塑性変形能力が決定された試験体，P $P \delta$ は曲げ面内変形 の増大に伴う $P \delta$ 効果によって載荷点での最大曲げモーメントおよび 塑性変形能力が決定された試験体， $P \delta+\mathrm{L}$ は $P \delta$ モーメントによる変 形で載荷点での最大曲げモーメントが決定され，その後曲げ面内の 最大変形位置付近に局部座屈変形が生じ, 耐力が低下した試験体を 示している。な扮崩壊形式の分類は, 載荷中に観察された試験体の 挙動, 試験体に貼付した歪ゲージから得た材長方向の分布, 曲げ面 内の変位履歴, $P \delta$ モーメントに対する考察から総合的に判断されて いる.

\section{3. 軸方向圧縮カと曲げモーメントを受ける角形鋼管柱の構造性能}

本章では Table 4 に示す実験結果に対して，LSD 指針・塑性指針が 定める制限式との比較を行う。LSD 指針旧版 ${ }^{13)}$ との比較も行う。

\section{1. 崩壊形式と材端塑性ヒンジ形成条件式の関係}

先述の通り LSD 指針や塑性指針では，軸方向圧縮力と $\kappa=0.0$ の曲 げモーメントを受ける柱に対して (2) 式を設けることで材端に塑性ヒ ンジを形成し, 塑性変形能力 $R=3 \sim 5$ 程度が確保できるとしている.

Fig. 2 に (2) 式,(6) 式の項である $n_{y} \cdot \lambda_{c 0}{ }^{2}$ と材端曲げモーメント比 $\kappa$ の 関係を示す。ここで，(2) 式を図中に実線で示している。また本論文 においては，材端に塑性ヒンジを形成する柱と実験により得られる 崩壊機構 C.M.:L を同義として考察を行う. Fig. 2 より, 軸方向圧縮 力と曲げモーメントを受ける角形鋼管柱に対し，(2) 式は崩壊形式を 確保するという点で一端曲げから逆対称曲げとなるにつ扎てやや安 全側となるが，塑性変形能力 3 以上という結果も満たしていること から, 概ね妥当な評価をしているといえる. また本実験結果の範囲 において，(2) 式との連続性を考慮する形で材端に塑性ヒンジを形成 し塑性変形能力 3 以上を確保する制限式として, 次式が提案できる.

$$
n_{y} \cdot \lambda_{c 0}^{2} \leqq \frac{0.4}{4-\kappa}(1+\kappa)
$$

(10) 式は Fig. 2 中に破線で示している.

\section{2. 塑性ヒンジ形成条件式を満たさない場合の耐力評価}

筆者らは文献 6) 8) において, LSD 指針が定める C-I 区分 ((7) 式) を満たす柱は以下に示す全塑性限界耐力式を上回ることを報告した.

$$
\begin{array}{rlrl}
\frac{N}{\phi_{p} N_{y}} & \leqq 0.15 \text { のとき } & & \frac{M}{\phi_{p} M_{p}}=1.0 \\
\frac{N}{\phi_{p} N_{y}}>0.15 \text { のとき } & \frac{N}{\phi_{p} N_{y}}+0.85 \frac{M}{\phi_{p} M_{p}}=1.0
\end{array}
$$

$\phi_{p}$ は全塑性モーメントに関わる耐力係数であり，文献 6) 8) では $\phi_{p}$ を 1.0 として考察を行った. 本節では(11)式が適用されない柱も含め,

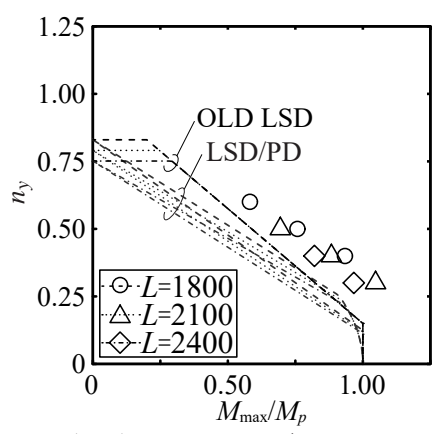

$(\mathrm{a}-1) \quad \kappa=0.0, \mathrm{~B} / \mathrm{t}=20.8$

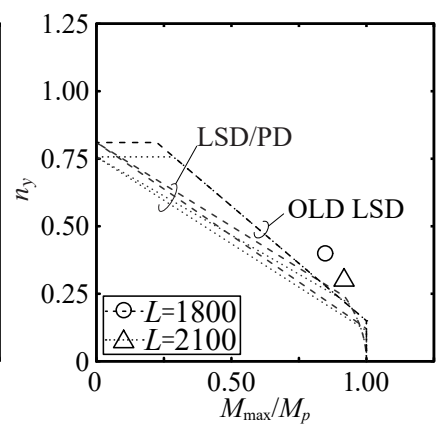

(a-2) $\kappa=0.0, \quad \mathrm{~B} / \mathrm{t}=16.7$

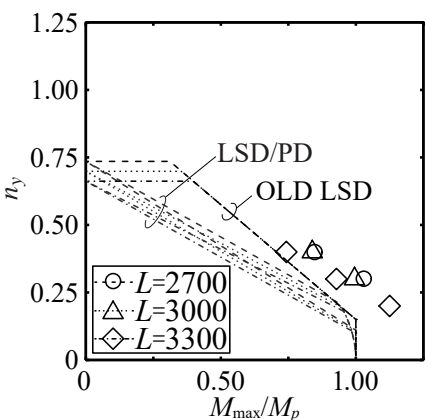

(b) $\kappa=0.5$

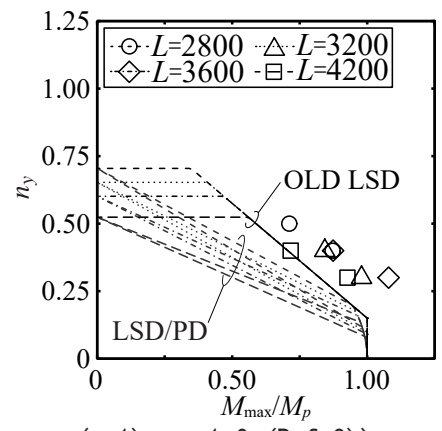

(c-1) $\kappa=1.0$, (Ref. 8)

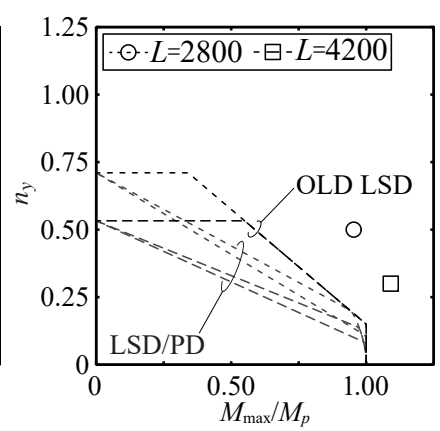

(c-2) $\kappa=1.0$, (Add)
Fig. 3 Comparison between maximum bending moment and strength formula per recommendations

実験結果と LSD 指針および塑性指針が定める耐力式との関係を考察 する．まず各指針における耐力式について概要を述べる.

現行の LSD 指針 (第三版)（Fig. 3では「LSD」と表記する)

LSD 指針において C-I 区分外となる角形鋼管柱は，(11) 式に示す全 塑性限界耐力と次式に示す曲げ圧縮限界耐力のうち小さい方で算出 する.

$$
\frac{N}{\phi_{c} N_{c}}+0.85 \cdot \varphi \cdot \frac{M}{\phi_{p} M_{p}}=1.0
$$

$\phi_{c}$ は曲げ座屈限界耐力に関わる耐力係数であり, 本論文においては $\phi_{c}$ を 1.0 とする. $N_{c}$ は曲げ座屈限界耐力であり, 次式により求められる.

$$
\begin{array}{ll}
\lambda_{c} \leqq{ }_{p} \lambda_{c} \quad \text { のとき } \quad N_{c}=N_{y} \\
{ }_{p} \lambda_{c}<\lambda_{c} \leqq{ }_{e} \lambda_{c} \text { のとき } \quad N_{c}=\left(1.0-0.5 \frac{\lambda_{c}-{ }_{p} \lambda_{c}}{{ }_{e} \lambda_{c}-{ }_{p} \lambda_{c}}\right) \cdot N_{y} \\
{ }_{e} \lambda_{c}<\lambda_{c} \quad \text { のとき } \quad N_{c}=\frac{1}{1.2 \lambda_{c}^{2}} \cdot N_{y}
\end{array}
$$

$\lambda_{c}$ は曲げ座屈細長比であり， $\lambda_{c 0}$ の算出における $L$ を曲げ座屈長さ $k_{c} L$ としたものに等しい. 一連の実験においては強軸まわりの曲げ座 屈長さ係数 $k_{c}$ は 1.0 となることから, 本研究では $\lambda_{c}=\lambda_{c 0}$ となる. また, ${ }_{p} \lambda_{c}$ は塑性限界細長比 $(=0.15), \lambda_{c}$ は弾性限界細長比 $(=1 / \sqrt{ } 0.6)$ である. 
また (12) 式中における $\varphi$ は圧縮軸力による二次モーメントを考慮し た補正係数であり, 塑性指針においてはモーメント拡大係数と定め られているものである。 $\varphi$ の算出式を以下に示す.

$$
\begin{array}{ll}
n_{y} \cdot \lambda_{c 0}^{2} \leqq 0.25(1+\kappa) \text { のとき } \quad \varphi=1.0 \\
n_{y} \cdot \lambda_{c 0}^{2}>0.25(1+\kappa) \text { のとき } \quad \varphi=\frac{1-0.5(1+\kappa) \sqrt{N / N_{0}}}{1-N / N_{0}}
\end{array}
$$

ここに示す算定式は, 非弾性状態での最大耐力時の曲げモーメント を算定する評価式として坂本らによって提案されたものである ${ }^{14)}$. なお，式中の $N / N_{0}$ は $n_{y} \cdot \lambda_{c 0}^{2}$ と等しい.

旧版の LSD 指針 (第二版)（Fig. 3 では「OLD LSD」と表記する)

LSD 指針第二版では，C-I 区分に属する角形鋼管柱の耐力式として (11) 式，C-I 区分外の角形鋼管柱に対して (11) 式と次式の小さい方で 評価するとされていた。

$$
\begin{aligned}
& \frac{N}{\phi_{c} N_{c X}} \leqq 1.0 \\
& \frac{N}{\phi_{c} N_{c Y}} \leqq 1.0 \\
& \frac{N}{\phi_{p} N_{y}}+0.85 \cdot \varphi \cdot \frac{M}{\phi_{p} M_{p}}=1.0
\end{aligned}
$$

$N_{c X}$ は曲げ面内の座屈限界耐力， $N_{c Y}$ は曲げ面外の座屈限界耐力で あり，材長 $L$ を用いて (13) 式により算出する。なお本論文における 考察では， $\phi_{p} お よ ひ ゙ \phi_{c}$ はいずれも 1.0 とした。

現行の塑性指針（Fig. 3では「PD」と表記する)

現行の塑性指針をみると，材端に塑性ヒンジを形成する柱の制限 である (2) 式を満たす柱に対して (4) 式に示す全塑性相関式を設けて いる。 また (2) 式を満たさない柱は，(16) 式で算出するとしている. なお，式中の $N_{c r}$ は (13) 式での $N_{c}$ と同義である .

$$
\begin{aligned}
& \frac{N}{N_{c r}}+\varphi \cdot \frac{4 A_{2}+A_{1}}{2 A} \cdot \frac{M}{M_{p}}=1.0 \\
& \frac{M}{M_{p c}} \leqq 1.0
\end{aligned}
$$

Table. 4 に示す実験結果のうち (2) 式を満たさない試験体の最大曲 げモーメントと各指針が定める耐力式の関係を Fig. 3 に示す。なお, ここでは軸方向圧縮力と曲げモーメントを受ける柱に関して最新の 耐力式を定めた塑性指針 (2017 年改定) に倣い，参照する耐力式を変 更した。そのため，一部の試験体は LSD 指針における C-I 区分に属 する柱であっても図中に示されているものが存在する。(2) 式を満た す柱については, 既報 (6)-8) において全塑性限界耐力式((11) 式) およ び全塑性相関式 ((4) 式) を上回ることが確認されていることから図示 していない.

Fig. 3 より，(2) 式を満たさない柱の最大曲げモーメントと現行 LSD 指針・塑性指針（Fig. 3 では「LSD/PD」と表記）の対応をみる と, 軸力比の大きい試験体の一部で耐力式が実験結果を過剩に安全 側で評価していることがわかる，現行の塑性指針に則り (2) 式を満た さない柱に対して耐力評価を行う場合，本実験結果の範囲では，高 軸力比であっても耐力低下の小さい LSD 指針第二版(Fig. 3 では「OLD LSD」と表記) の定める耐力式が最も適切であるということができる.

\section{3. モーメント拡大係数の評価}

前節で言及したように LSD 指針・塑性指針では，(2)式を満たさず 材端に塑性ヒンジを形成しない柱に対して, 部材中間に最大曲げモー メントが生じる場合の最大曲げモーメントを材端曲げモーメントか

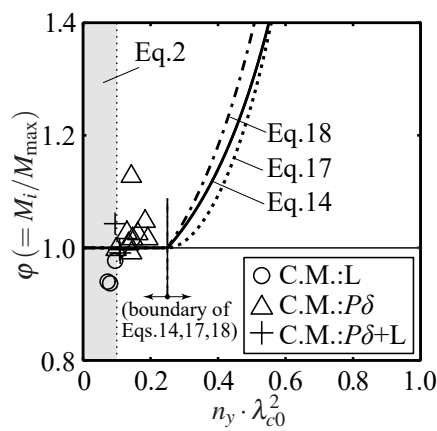

(a) $\kappa=0.0$

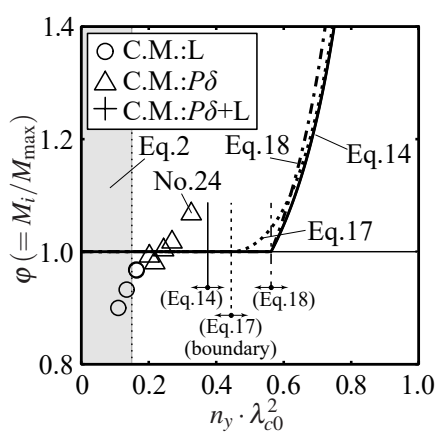

(b) $\kappa=0.5$

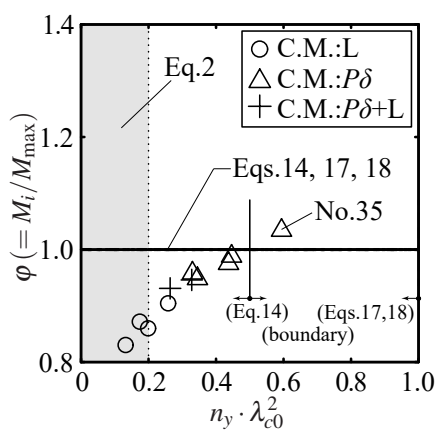

(c) $\kappa=1.0$

Fig. 4 Comparison between

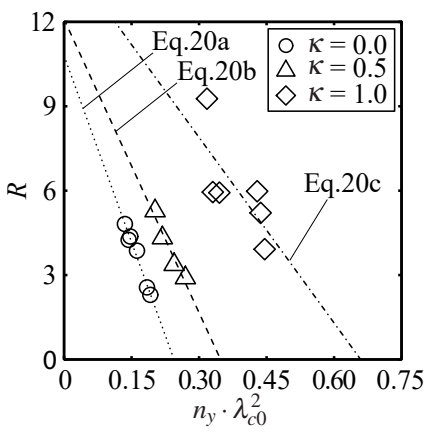

(a) C.M. : P $\delta$ $\mathrm{M}_{\mathrm{i}} / \mathrm{M}_{\max }$ and Eqs. 14, 17, 18

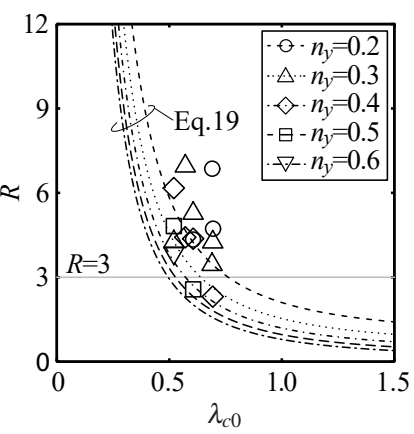

(a) $\kappa=0.0$

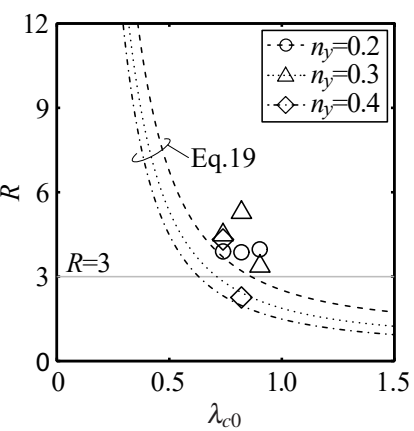

(b) $\kappa=0.5$

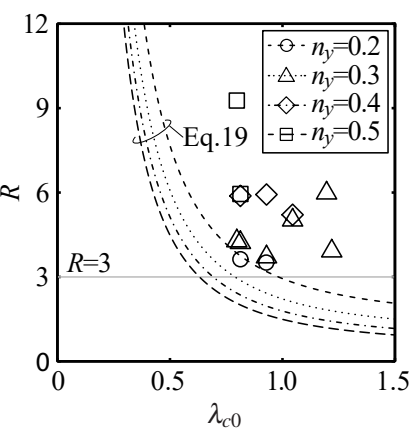

(c) $\kappa=1.0$

Fig. 5 Comparison between $\mathrm{R}$ and Eq. 19

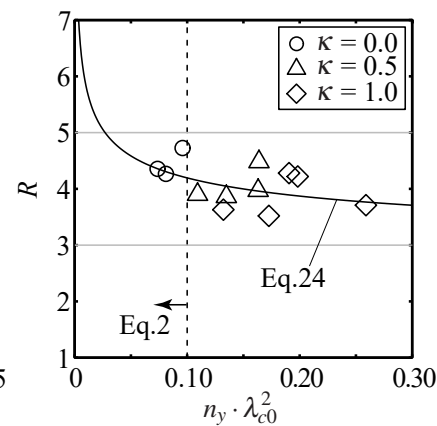

(b) C. M. :L
Fig. $6 \mathrm{R}-\mathrm{n}_{\mathrm{y}} \lambda_{\mathrm{co}}^{2}$ relationship ( $\left.\mathrm{B}=125 \mathrm{~mm}, \mathrm{t}=6 \mathrm{~mm}\right)$

ら算定する係数 (モーメント拡大係数 ) として, (14) 式を定めている. 塑性指針では追加条件として $\varphi \geqq 1.0^{10)}$ を定めている.

Table 4 に示した実験結果から，材端における最大曲げモーメント $M_{\text {max }}$ と変位計測位置における $P \delta$ 効果による付加曲げを考慮した曲げ モーメントの最大值 $M_{i}$ の比率 $\left(M_{i} / M_{\max }\right)$ を $\varphi$ とし, その結果と (14) 式 $(\varphi$ $\geqq 1.0$ の追加条件を含む）との対応を Fig. 4 に示す．図中には，柱に 元たわみがない場合の弾性解析より導出されるモーメント拡大係数 
((17) 式) ${ }^{2), 3)}$ と城戸・津田らによって提案された元たわみのない弾 性柱のモーメント拡大係数評価式（(18) 式） ${ }^{11)}$ も示している. また, Fig. 4 中には材端塑性ヒンジを形成する柱の制限である (2) 式（灰色 で塗られた領域)，モーメント拡大係数を求める (14) 式，(17) 式，(18) 式それぞれの評価式の分岐位置（(14) 式の分岐位置は材端初期降伏 の条件である (6) 式となる) も示している，なお，参考值である試験 体（No. 36 38）については $M_{i} / M_{\max }$ のプロットを行っていない.

$$
\begin{aligned}
& \kappa \geqq-\cos \left(\pi \sqrt{N / N_{0}}\right) \text { のとき } \\
& { }_{e} \varphi=1.0 \\
& \kappa<-\cos \left(\pi \sqrt{N / N_{0}}\right) \text { のとき } \\
& e=\frac{\sqrt{1+\kappa^{2}+2 \kappa \cos \left(\pi \sqrt{N / N_{0}}\right)}}{\sin \left(\pi \sqrt{N / N_{0}}\right)}
\end{aligned}
$$

$$
\begin{gathered}
n_{y} \cdot \lambda_{c 0}^{2} \leqq 0.25(1+\kappa)^{2} \text { のとき } \\
e \varphi=1.0 \\
n_{y} \cdot \lambda_{c 0}^{2}>0.25(1+\kappa)^{2} \text { のとき } \\
e \varphi=\frac{1+0.3\left(N / N_{0}\right)-0.65(1+\kappa) \sqrt{N / N_{0}}}{1-N / N_{0}}
\end{gathered}
$$

LSD 指針・塑性指針が定める (14) 式に従えば，材端曲げモーメン ト比 $\kappa$ が 0.0 あるいは 0.5 の場合では (6) 式を満たすことで $\varphi=1.0$ と なり， $\kappa=1.0$ の場合では $\varphi \geqq 1.0^{2), 10)}$ という追加条件により $n_{y} \cdot \lambda_{c 0}{ }^{2}$ の值 に関わらず $\varphi=1.0$ となることがわかる。しかし Fig. 4 をみると，実 験より得られる $M_{i} / M_{\text {max }}$ は (14) 式を上回る場合がある. Table 4 に示 したように, 試験体 No.24, No.35 以外では材端曲げモーメントが断 面の性能である全塑性モーメント $M_{p c}$ に到達していることから, 材端 での曲げモーメントが最大曲げモーメント時に $M_{i} / M_{\max }$ が 1.0 を超え ても問題はないといえる。一方で, 試験体 No.24, No.35 は材端曲げモー メントが全塑性モーメント $M_{p c}$ に到達せず， $M_{i} / M_{\text {max }}$ が 1.0 を超える 結果となったが, モーメント拡大係数は $\varphi=1.0$ と算定されているこ とから部材中の最大曲げモーメントを適切に評価できておらず，危 険側の評価となっている. 元たわみのない弾性柱から導出されたモー メント拡大係数評価式（(17) 式，(18) 式）は, 非弾性状態の柱から提 案された (14)式とおおよそ同じ傾向となった。

本研究では, 材端曲げモーメントが全塑性モーメント $M_{p c}$ に到達 しない柱が 2 体のみであることから, 非弾性状態の柱の最大曲げモー メントを算定する評価式と適用する評価式の分岐位置については, 更なる実験デー夕収集ののち, 再度考察する必要があるといえる.

\section{4. 塑性変形能力の評価}

塑性指針では，H 形鋼柱を対象とした実験結果に基づく塑性変形 能力評価式 ${ }^{5)}$ として次式を示している.

$$
R=\frac{0.15 \cdot(3.7+\kappa)}{\sqrt{N / N_{y}}} \cdot\left(\frac{1}{\lambda_{c 0}^{2}}+1.5\right)-1
$$

Fig. 5 に(19) 式と一連の実験結果との対応を示す。なおここでは $M_{p c}$ に到達しなかった試験体はプロットを行っていない. Fig. 5 より, 角形鋼管柱を対象とした場合の実験結果と評価式の対応は $\kappa=0.0$ の 場合が最も良く, 複曲率曲げとなるにつれて評価式が安全側となる 傾向がみられる。

一連の実験における塑性変形能力の評価について，既報 (6)-8)では C.M.: $P \delta$ となった試験体で $n_{y} \cdot \lambda_{c 0}{ }^{2}$ と塑性変形能力 $R$ の間に負の線形相 関がみられることを報告している. Table 4 に示した $B=125 \mathrm{~mm}, t=$

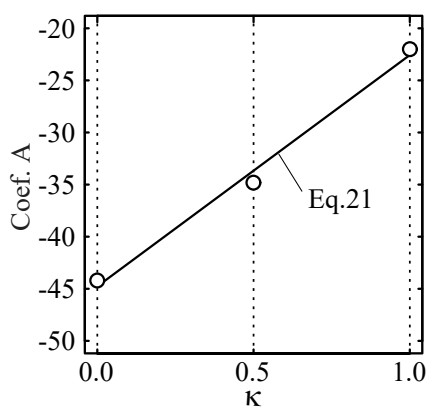

(a) Coefficient $\mathrm{A}$

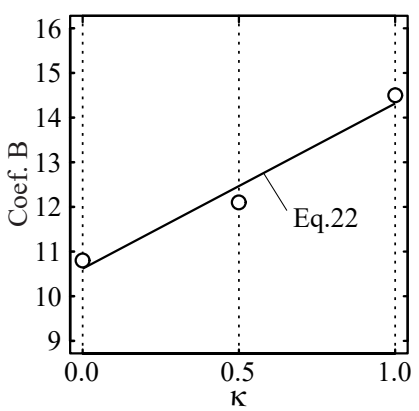

(b) Coefficient $B$
Fig. 7 Relationship between coefficients $A, B$ and $\kappa$

$6 \mathrm{~mm}$ の試験体について, C.M.:P 2 となつた試験体の $R-n_{y} \cdot \lambda_{c 0}{ }^{2}$ 関係およ び線形回帰により得られる直線式を Fig. 6 (a) に示す。図中の直線式 は以下の通りとなる.

$$
\begin{array}{ll}
\kappa=0.0 \text { のとき } & R_{\mathrm{C} . \mathrm{M} . \mathrm{P} \delta}=-44.2 \cdot\left(n_{y} \cdot \lambda_{c 0}^{2}\right)+10.8 \\
\kappa=0.5 \text { のとき } & R_{\mathrm{C} . \mathrm{M} . \mathrm{P} \delta}=-34.8 \cdot\left(n_{y} \cdot \lambda_{c 0}^{2}\right)+12.1 \\
\kappa=1.0 \text { のとき } & R_{\mathrm{C} . \mathrm{M} . \mathrm{P} \delta}=-22.0 \cdot\left(n_{y} \cdot \lambda_{c 0}^{2}\right)+14.5
\end{array}
$$

なお，(20.c) 式は既報 ${ }^{8)}$ から $M_{p c}$ 未到達の 1 試験体を除き，追加実 験の結果を含めて再評価している。これらの式の相関係数はそれぞ れ (20.a) 式:-0.990, (20.b) 式:-0.976, (20.c) 式:-0.733である. 線形回帰 に用いた関数 $y=\mathrm{A} x+\mathrm{B}$ の係数 $\mathrm{A}, \mathrm{B}$ と材端曲げモーメント比 $\kappa$ の関係 を Fig. 7 に示す. 図中には線形回帰より得られた直線式も示している. 図中の直線式は以下の通りとなる。

$$
\begin{aligned}
& \mathrm{A}=22.2 \kappa-44.8 \\
& \mathrm{~B}=3.7 \kappa+10.6
\end{aligned}
$$

これらの式の相関係数はそれぞれ(21) 式:0.996, (22) 式:0.986であ る.したがって, 材端曲げモーメント比 $\kappa$ を陽に反映した C.M.:P $P$ の 塑性変形能力は次式で表現できる。ただし, 補間された材端曲げモー メント比 $\kappa$ にいては実験等での確認が必要である.

$R_{\mathrm{C} . \mathrm{M} .: P \delta}=(22.2 \kappa-44.8)\left(n_{y} \cdot \lambda_{c 0}^{2}\right)+(3.7 \kappa+10.6)$

本論文では軸方向圧縮力と曲げモーメントを受ける柱の塑性変形 能力 $R$ を $n_{y} \cdot \lambda_{c 0}{ }^{2}$ との関係で整理するため, C.M.:L となった試験体に ついても $R-n_{y} \cdot \lambda_{c 0}{ }^{2}$ の関係を Fig. 6(b) に示す．柱の材端に塑性ヒンジ を形成し，軸方向力を保持した状態で塑性変形能力を確保するため の制限である (2) 式によれば， $\kappa$ の值が大きくなる程 C.M.:L となる $n_{y} \cdot \lambda_{c 0}{ }^{2}$ の上限值が大きくなる. Fig. 6(b) より, 本実験結果は $\kappa$ の増加 に伴う $n_{y} \cdot \lambda_{c 0}{ }^{2}$ の拡張に対応して広く分布しており， $\kappa$ の值によらず非 線形の相関が考えられる. そこでFig. 6(b) に示すようにC.M.:L となつ た全試験体に対して非線形回帰を行い，次式を得た。

$$
R_{\mathrm{C} . \mathrm{M} . \mathrm{L}}=\left(n_{y} \cdot \lambda_{c 0}^{2}\right)^{-0.243}+2.45
$$

統計解析の結果，モデル関数 $y=x^{\mathrm{a}}+\mathrm{b}$ について得られる係数の $\mathrm{p}$ 值 はそれぞれ a: $0.0575, \mathrm{~b}: 7.79 \times 10^{-5}$ となった。

(20) 式あるいは (23) 式, (24) 式を用いて軸方向圧縮力と曲げモーメ ントを受ける柱の塑性変形能力を評価する場合, 各式が回帰分析に より得られたものであることから，実験值のばらつきを考慮して補 正を行ったのち, 各式から求まる值の小さい方を評価值とするといっ た方法が考えられる。また，一連の実験において C.M.:L となった試 験体はいずれも公称幅厚比が 20.8 であり, 幅厚比の増減に伴い評価 式((24) 式)も補正されることが必要となる．これに関しては今後の 課題といえる. 


\section{4. まとめ}

本論文では既報 ${ }^{6)-8)}$ の結果を用い，材端曲げモーメント比の影響 を考慮した崩壊形式/最大曲げモーメント/塑性変形能力について, LSD 指針・塑性指針との比較検討を行った，以下に結論をまとめる.

1） LSD 指針・塑性指針が材端に塑性ヒンジを形成する柱に対して定 める軸力比・細長比の組合せ制限と一連の実験における試験体の 崩壊形式との対応を見ると，各指針の制限は崩壊形式および塑性 変形能力確保の観点から安全側の評価となる。本論文では一連の 実験結果に基づき，指針の定める制限式に沿う形で，崩壊形式お よび塑性変形能力 3 以上を確保する制限として (10) 式を示した.

2) 一連の実験から得られる最大曲げモーメントと各指針の定める耐 力式との比較を行い，材端に塑性ヒンジを形成する制限を満たさ ない柱の最大曲げモーメントが低く見積もられている点に言及し た．本論文では一連の実験結果に基づき，材端に塑性ヒンジを形 成する制限を満たさない角形鋼管柱の耐力を見積もる際に LSD 指針第二版の定める耐力式 ((15) 式) が最も妥当であることを示 した.

3) 一連の実験から得られた材端の最大曲げモーメント $M_{\text {max }}$ と変位 計測位置における付加曲げを考慮した曲げモーメントの最大值 $M_{i}$ の比率 $M_{i} / M_{\max }$ をモーメント拡大係数 $\varphi$ と定め, LSD 指針・塑 性指針が定めるモーメント拡大係数算定式 ((14) 式, 追加条件 $\varphi \geqq$ 1.0 を含む) との比較を行った。その結果，実験值が計算值を上 回る場合があることを示した，材端曲げモーメントが全塑性モー メント $M_{p c}$ に到達しなかった柱であっても, 現行指針ではモーメ ント拡大係数が 1.0 と危険側の評価となったため, 部材の最大曲 げモーメントを算定する評価式と適用する評価式の分岐位置につ いては更なるデー夕の構築ののち, 再度考察する必要がある.

4) 一連の実験から得られた塑性変形能力 $R$ と $\lambda_{c 0}$ の関係から, 塑性 指針に示されている評価式は複曲率曲げを受ける場合に実験值と 乘離する傾向がみられた。本研究では制限式の項として用いられ る $n_{y} \cdot \lambda_{c 0}{ }^{2}$ を用い, 実験結果に基づき崩壊形式毎の塑性変形能力評 価式を示した。本評価式は実験結果の回帰分析より得たものであ ることから，実験值のばらつきを考慮して適切な補正を行う必要 がある，また，幅厚比の変化に対する補正項の導入等が今後の課 題といえる.

\section{謝辞}

本研究は日本鉄鋼連盟・鋼構造研究支援助成金（代表 : 佐藤篤司 $)$ を受けて行ったものである。ここに付して感謝の意を表す。

\section{参考文献}

1) Architectural Institute of Japan: Recommendation for Limit State Design of Steel Structures, 2010.2 (in Japanese) 日本建築学会 : 鋼構造限界状態設計指針・同解説 , 2010.2

2) Architectural Institute of Japan: AIJ Recommendations for Plastic Design of Steel Structures, 2017.2 (in Japanese) 日本建築学会 : 鋼構造塑性設計指針, 2017.2

3) Architectural Institute of Japan: Recommendations for Stability Design of Steel Structures, 2018.2 (in Japanese) 日本建築学会 : 鋼構造座屈設計指針, 2018.2

4) Architectural Institute of Japan: Design Standard for Steel Structures - Based on Allowable Stress Concept -, 2005.9 (in Japanese) 日本建築学会 : 鋼構造設計規準 - 許容応力度設計法 -, 2005.9
5) Ishida, T., Ono, T. and Nomoto, S.: Study on Design Criteria of Steel BeamColumns Based on Experimental Data, Summaries of Technical Papers of Annual Meeting, Architectural Institute of Japan, C, Structures II, pp. 1287-1288, 1989.10 (in Japanese)

石田交広, 小野徹郎, 野元覚 : 実験デー夕に基づく鉄骨曲げ柱の設計規範 に関する一考察, 日本建築学会大会学術講演梗概集, C, 構造 II , pp. 12871288, 1989.10

6) Sato, A. and Mitsui, K.: EXPERIMENTAL STUDY ON SQUARE STEEL TUBULAR COLUMNS UNDER COMPRESSIVE AXIAL FORCE WITH ONE END MONOTONIC BENDING MOMENT, Journal of Structural and Construction Engineering (Transactions of AIJ), Vol.81, No.729, pp. 1933-1943, 2016.3 (in Japanese)

佐藤篤司, 三井和也 : 軸方向圧縮力と一端単調曲げモーメントを受ける角 形鋼管柱の実験的研究, 日本建築学会構造系論文集, 第 81 巻, 第 729 号, pp. 1933-1943, 2016.3

7) Sato, A., Inden, K. and Mitsui, K.: EXPERIMENTAL STUDY ON SQUARE STEEL TUBULAR COLUMNS UNDER COMPRESSIVE AXIAL FORCE WITH MONOTONIC DOUBLE CURVATURE BENDING MOMENT, Journal of Structural and Construction Engineering (Transactions of AIJ), Vol.83, No.747, pp.739-749, 2018.5 (in Japanese)

佐藤篤司, 位田健太, 三井和也 : 軸方向圧縮力と単調複曲率曲げモーメント を受ける角形鋼管柱の実験的研究 材端曲げモーメント比を 0.5 とした場合, 日本建築学会構造系論文集, 第 83 巻,第 747 号, pp. 739-749, 2018.5

8) Sato, A. and Mitsui, K.: EXPERIMENTAL STUDY ON SQUARE STEEL TUBULAR COLUMNS UNDER COMPRESSIVE AXIAL FORCE WITH MONOTONIC ANTISYMMETRIC BENDING MOMENT, Journal of Structural and Construction Engineering (Transactions of AIJ), Vol.82, No.732, pp. 267-277, 2017.2 (in Japanese)

佐藤篤司, 三井和也 : 軸方向圧縮力と単調逆対称曲げモーメントを受ける 角形鋼管柱の実験的研究, 日本建築学会構造系論文集, 第 82 巻, 第 732 号, pp.267-277, 2017.2

9) Sato, K.: EVALUATION METHOD FOR STRUCTURAL PERFORMANCE OF SQUARE HOLLOW SECTION COLUMN MEMBERS BY NEW NORMALIZED WIDTH-THICKNESS RATIO, Proceedings of Constructional Steel, Vol. 25, pp. 233-238, 2017.11 (in Japanese)

佐藤公亮 : 正方形中空断面柱部材の新規幅厚比尺度による構造性能評価法, 鋼構造年次論文報告集, 第 25 巻,pp. 233-238, 2017.11

10) Tsuda, K. and Kido, M.: ULTIMATE STRENGTH OF SQUARE STEEL TUBULAR BEAM-COLUMNS WITH ELASTIC-PERFECTLY PLASTIC MATERIALS, Journal of Structural and Construction Engineering (Transactions of AIJ), Vol.80, No.718, pp. 1981-1990, 2015.12 (in Japanese)

津田惠吾 , 城戸將江 : 完全弾塑性型の応力 - ひずみ関係よりなる角形鋼管柱 の終局耐力評価について, 日本建築学会構造系論文集, 第 80 巻, 第 718 号, pp. 1981-1990, 2015.12

11) Haraguchi, M., Kido, M. and Tsuda, K.: PROPOSAL OF EQUATION FOR EVALUATING MOMENT AMPLIFICATION FACTOR OF ELASTIC BEAMCOLUMNS, Proceedings of Constructional Steel, Vol. 25, pp. 774-781, 2017.11 (in Japanese)

原口将行, 城戸將江, 津田惠吾 : 弾性柱の曲げモーメント拡大係数評価式の 提案, 鋼構造年次論文報告集, 第 25 巻, pp. 774-781, 2017.11

12) Inoue, K. and Suita, K.: Kenchikukoukouzou -Sono Riron to Sekkei- (Steel Structure -Theory and Design-), Kajima Institute Publushing, 2013.2 (in Japanese) 井上一朗, 吹田啓一郎 : 建築鋼構造 - その理論と設計 -, 鹿島出版, 2013.2

13) Architectural Institute of Japan: Recommendation for Limit State Design of Steel Structures, 2002.9 (in Japanese) 日本建築学会 : 鋼構造限界状態設計指針・同解説, 2002.9

14) Sakamoto, J., Miyamura, A. and Watanabe, M.: THE PLASTIC INTERACTION FORMULAE OF THE STEEL BEAM-COUMNS (Part I), Transactions of the Architectural Institute of Japan, No. 149, pp. 9-15, 1968.7 (in Japanese) 坂本順, 宮本篤典, 渡辺雅生 : 鋼構造圧縮材の塑性耐力式に関する考察そ の 1 , 日本建築学会論文報告集, 第 149 号 ,pp. 9-15, 1968.7 


\title{
STRUCTURAL PERFORMANCE EVALUATION OF SQUARE STEEL TUBULAR COLUMN UNDER COMPRESSIVE AXIAL FORCE WITH BENDING MOMENT
}

\author{
Atsushi SATO ${ }^{* 1}$, Kenta INDEN ${ }^{* 2}$ and Kazuya MITSUI ${ }^{* 3}$ \\ ${ }^{* 1}$ Assoc. Prof., Graduate School of Engineering, Nagoya Institute of Technology, Dr.Eng./ \\ Frontier Research Institute for Information Science (FRIIS) \\ ${ }^{* 2}$ Former Grad. Student, Nagoya Institute of Technology, M.Eng. \\ (Present Toyota Housing Co.) \\ ${ }^{* 3}$ Former Nagoya Institute of Technology, Dr.Eng. \\ (Present Steel Structures Research Lab., Nippon Steel \& Sumitomo Metal Co.)
}

Square steel tubular columns are widely used in moment resisting frames. The moment resisting frame system will resist the horizontal load action through the flexural manner of the columns. Therefore, the columns will subject the axial force and the bending moment simultaneously. Under the seismic action, the effect of the bending moment that is the result of the shear force subjected to the column will be significant; the structural safety of the column at the ultimate limit state (ULS) shall be guaranteed. Recommendation for Limit State Design of Steel Structures and Recommendation for Plastic Design of Steel Structures specifies the requirements for the column to guarantee sufficient strength and ductility at the ULS. However, the appropriateness of requirements for square steel tubular column is not verified clearly. The test results, where the square steel tubular columns are under compressive axial force with different moment distribution, were reported in the previous papers. In this paper, structural performance evaluation of square steel tubular column is conducted based on the existing test results. Collapse mode, maximum bending moment, plastic deformation capacity, and moment amplification factor are evaluated; comparison study between the current design recommendation is also shown.

This study revealed the following results

1) The design requirement (Eq. (2)) that is specified for the column expected to form the plastic hinge provided conservative results. The gap between the collapse mode observed from the testing and that is expected in the design requirements gets larger when the moment distribution will get close to antisymmetric bending moment. In this study, Eq. (10) is shown to evaluate the collapse mode reasonably. Moreover, Eq. (10) still fulfill the required minimum plastic deformation capacity that is stipulated in the recommendations.

2) Design strength of the column which will not fulfill the requirements for the column to form plastic hinge showed conservative results when it was computed from current recommendations. The design strength computed from the old version of the recommendation provided more reasonable results.

3) Moment amplification factor that is used to evaluate the $P \delta$ effects was compared with the test result. It was confirmed that some columns showed unconservative results at the ultimate limit state. The column categorized to have no $P \delta$ effects per Eq. (14) but could not resist full plastic moment (i.e., $M_{p c}$ ) during the test showed large second-order effects. In this case, the maximum bending moment through the column cannot be evaluated appropriately. However, this kind of phenomenon was observed in two specimens only. A further study shall be needed for the evaluation.

4) Large deviation was observed at the plastic deformation capacity of the column under the double curvature bending when it was compared with the formula that is proposed for one end bending moment condition. From the regression analysis, the formulae that will evaluate the plastic deformation capacity of the column were shown. The derived formulae are not including the parameter of the width-to-thickness ratio; therefore, further study shall be needed for the proposal. 